\title{
Study of Variation of Plant Types of Vertical SubSurface Constructed Wetland Treating Groundwater Contaminated with Iron (Fe)
}

\author{
Nopi Stiyati Prihatini' ${ }^{1}$, Indah Nirtha², Riza Miftahul Khair ${ }^{3}$, Alfiyyah Nahdah ${ }^{4}$ \\ ${ }^{1-4}$ Environmental Engineering Study Program, Faculty of Engineering, Lambung Mangkurat University, Jl. A. \\ Yani Km. 37, Banjarbaru, South Kalimantan , Indonesia, Postal Code 70714
}

Corresponding Author: Nopi Stiyati Prihatini

DOI: https://doi.org/10.52403/ijrr.20220174

\begin{abstract}
Drilling groundwater at the BSD Housing Complex, Malintang Village, Gambut District, Banjar Regency has an iron $(\mathrm{Fe})$ value of 5.98 $\mathrm{mg} / \mathrm{L}$. According to the Minister of Health Number 32 of 2017 concerning water health requirements for hygiene and sanitation purposes, the water is above the quality standard, $1.0 \mathrm{mg} / \mathrm{L}$ for Iron $(\mathrm{Fe})$. One of the treatment methods used to treat the contaminated groundwater is constructed wetland $(\mathrm{CW})$. $\mathrm{CW}$ was chosen because of its relatively low cost and environmentally sound natural wetlands. We used the Vertical Flow Subsurface Constructed Wetland (VSSF-CW) in this study. This study aims to determine the effectiveness of the VSSF-CW system with different local plants, namely Jeringau (Acorus calamus) and Purun tikus (Eleocharis dulcis), in removing iron $(\mathrm{Fe})$ in groundwater. The study used five wood reactors with $90 \mathrm{~cm}$ x 30 $\mathrm{cm} \times 40 \mathrm{~cm}$. The results showed that the VSSF$\mathrm{CW}$ system with $E$. dulcis plant effectively removed iron $(\mathrm{Fe})$ with a higher efficiency value of $85.68 \%$ compared to the reactor with $A$. calamus plant that was $76.72 \%$, and reactor without plant $59,37 \%$. The lowest efficiency of each reactor during the study was on day 5 , with values of $58.28 \%, 37.88 \%$, and $29.43 \%$, respectively. The concentration of iron $(\mathrm{Fe})$ in the VSSF-CW system effluent with Acorus calamus and Eleocharis dulcis plants for 40 days has a value that tends to decrease.
\end{abstract}

Keywords: Vertical Flow Subsurface Constructed Wetland, groundwater, iron, Acorus calamus, Eleocharis dulcis

\section{INTRODUCTION}

Gambut Subdistrict in Indonesia is an area that is swampy and peaty, so the site has high levels of heavy metals such as iron (Fe). It can be seen from the water's physical characteristics, which are yellowish ${ }^{[1,2]}$. Some people in Gambut Subdistrict still use groundwater to meet basic needs in their daily life. However, the usage of groundwater that has a high iron $(\mathrm{Fe})$ content used in the long term can negatively impact health ${ }^{[3]}$.

The groundwater used by the community is based on a preliminary study conducted in February 2019 in one of the resident's wells in the BSD Housing Complex, Malintang Village, Gambut District, Banjar Regency, which has an iron (Fe) value of $5.98 \mathrm{mg} / \mathrm{L}$. Meanwhile, the quality standard determined by the Minister of Health Number 32 of 2017 concerning water health requirements for sanitation hygiene purposes is $1.0 \mathrm{mg} / \mathrm{L}$ for Iron $(\mathrm{Fe})$. The water has physical characteristics: yellow water, smells (usually iron or rust), and slightly slippery water ${ }^{[2]}$. It can cause rust on the faucet. The groundwater used by the community to meet the needs of clean water does not meet health standards because if the water is used in the bath, it 
will give sediment and yellowish stains. The water is above the specified quality standard, so it requires a treatment process before using it.

In developing countries, waste treatment can only be sustainable with the criteria of economic cost and appropriate technology. The Constructed Wetland System (CW) is a technology that meets these criteria because $\mathrm{CW}$ is relatively lowcost and environmentally sound based on the concept of natural wetlands ${ }^{[4,5]}$. This study uses Vertical Subsurface Flow Constructed Wetlands (VSSF-CW) because it can treat water contaminated with heavy metals with high treatment efficiency (above $80 \%)^{[2,6]}$. The flow is used with a continuous system because the flow is more effective than the batch system ${ }^{[7,8]}$.

The Subsurface Vertical Flow Constructed Wetlands system use Jeringau (Acorus calamus) and Purun Tikus (Eleocharis dulcis) plants. These two plants were chosen because of their ability to live in wetland areas with heavy metal content and reduce heavy metal levels of iron $(\mathrm{Fe})$. The A. calamus plant can absorb heavy metals of $0.05 \mathrm{mg} / \mathrm{L}$ or $14.29 \%{ }^{[9]}$. Meanwhile, the E. dulcis plant removed iron (Fe) by $98.26 \%{ }^{[10]}$. Constructed wetlands to treat groundwater with $A$. calamus and $E$. dulcis plants have not been studied. So this research on the effectiveness of the Vertical Subsurface Flow Constructed Wetland System (VSSF-CW) with the different plants to remove heavy metal iron $(\mathrm{Fe})$ in groundwater is necessary.

\section{MATERIALS AND METHODS}

This study will use a wood reactor coated with plastic with the size of each reactor, which is $90 \mathrm{~cm} \times 30 \mathrm{~cm} \times 40 \mathrm{~cm}$. Five reactors were assembled into a VSSF$\mathrm{CW}$ system using media mixture soil and $10 \%$ cow manure. The first reactor is VSSF$\mathrm{CW}$ without plant (Control), the other reactors planted with Jeringau (Acorus calamus) and Purun Tikus (Eleocharis dulcis), with an average plant height of 30 $\mathrm{cm}$. The running process of the reactor was fed groundwater at VSSF-CW for 40 days with sampling every five days. The concentration of iron in the effluent was carried out by laboratory analysis according to the Indonesian standard, namely SNI 6989.4:2009. The iron (Fe) total analysis method is by Atomic Absorption Spectrophotometry (AAS). Measurement of total iron concentration was carried out at the inlet and outlet of the VSSF-CW reactor. The efficiency of the VSSF-CW system is determined using the formula in equation 1 . [11]

$E=\frac{c_{0}-c_{e}}{c_{0}} \times 100 \% \ldots \ldots . .($ equation 1$)$

Anotation:

$\mathrm{E}=$ Efficiency $(\%)$

$\mathrm{C}_{0}=$ inlet iron concentration $(\mathrm{mg} / \mathrm{l})$

$\mathrm{Ce}=$ outlet iron concentration $(\mathrm{mg} / \mathrm{l})$

\section{Statistical Methods}

The data obtained are correctly summarized and regularly made in tables, graph percentages such as scatters, and line charts to determine the effluent's iron $(\mathrm{Fe})$ concentration dynamics. Analysis to predict the concentration of Iron $(\mathrm{Fe})$ with the regression method and One Way ANOVA statistical test to determine whether each treatment affects the efficiency of the VSSF-CW system and has a significant difference.

RESULT

Table 3.1 Measurement Results of Iron (Fe) in Well Water Effluent

\begin{tabular}{|l|l|l|l|l|}
\hline \multirow{2}{*}{ Time (days) } & \multirow{2}{*}{ Inlet } & \multicolumn{2}{|l|}{ Fe Concentration $(\mathbf{m g} / \mathbf{L})$} \\
\cline { 3 - 5 } & & \multicolumn{2}{|l|}{ Outlet } & \multicolumn{2}{|l|}{ Control $\mathbf{( C )}$} & Acorus Calamus $(\mathbf{A C})$ & Eleocharis Dulcis $($ ED) \\
\cline { 3 - 5 } & & 4,22 & 3,72 & 2,50 \\
\hline 5 & 5,98 & 4,10 & 3,56 & 1,78 \\
\hline 10 & 5,69 & 3,91 & 2,81 & 0,82 \\
\hline 15 & 5,67 & 3,32 & 2,70 & 0,96 \\
\hline 20 & 5,39 & 2,19 & 1,26 & 1,07 \\
\hline 25 & 5,32 & 2,54 & 1,32 & 1,20 \\
\hline 30 & 5,27 & 2,70 & 1,68 & 1,55 \\
\hline 35 & 5,05 & 2,95 & 1,53 & 1,32 \\
\hline 40 & & &
\end{tabular}


Nopi Stiyati Prihatini et.al. Study of variation of plant types of vertical subsurface constructed wetland treating groundwater contaminated with Iron ( $\mathrm{Fe})$.

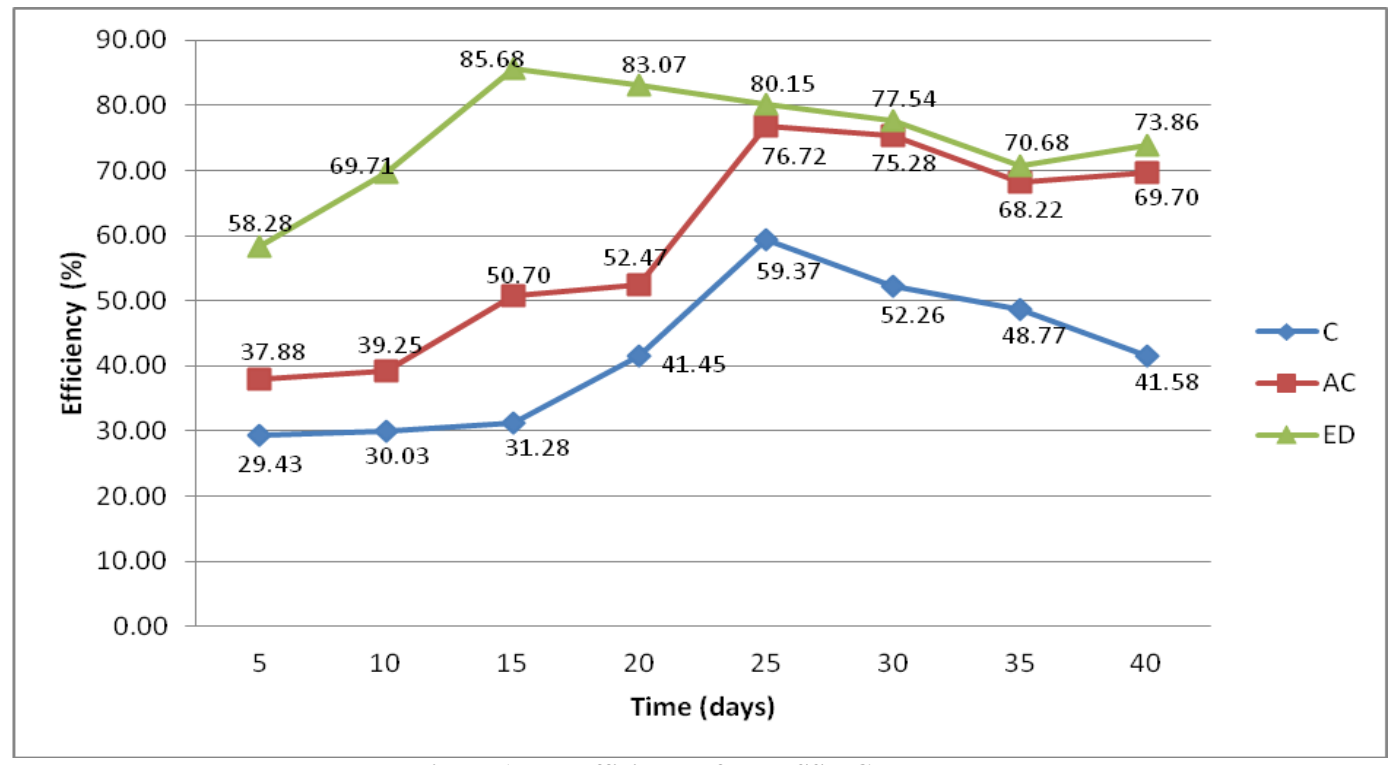

Figure 1. The efficiency of the VSSF-CW system

The results of the total iron concentration analysis of the VSSF-CW system are presented in Table 1. The efficiency of the VSSF-CW system is shown in Figure 1.

It can be seen that is based on the efficiency value, Eleocharis dulcis plants were more significant in influencing the efficiency of VSSF-CW compared to the VSSF-CW system with Acorus calamus plants. However, this statement is not necessarily appropriate; statistical tests are needed to ascertain whether each treatment affects the efficiency of the VSSF-CW system. Based on the results of the analysis, the value of Shapiro-Wilk Sig concentration of Iron $(\mathrm{Fe})$ with VSSF-CW system using Acorus calamus ; Eleocharis dulcis and Control i.e. 0.212; 0.325 and 0.484 , which means $>0.05$ so that the data is a normal distribution. The homogeneity test also shows the value of Sig. Levene concentration of Iron $(\mathrm{Fe})$, which is 0.113 , shows $>0.05$ so that the data is homogeneous, then the analysis can be carried out with the One Way ANOVA test. The value of the concentration of iron $(\mathrm{Fe})$ is 0.000 , which indicates the value of Sig. ANOVA $<0.05$ suggests a significant difference in the average concentration of Iron $(\mathrm{Fe})$ with VSSF-CW with different plants.
The results in Table 1 showed that most of the concentration of Iron (Fe) in the VSSF-CW system was still above the quality standard according to the Indonesian Minister of Health Number 32 of 2017 concerning water health requirements for sanitation hygiene purposes, namely $1.0 \mathrm{mg} / \mathrm{L}$ for Iron (Fe). So it is necessary to build a mathematical model to predict the concentration of iron in the effluent of the VSSF-CW system to meet the quality standards set in Indonesia. A trendline is added to the Fe concentration data chart, and then we determine one of any of the six different trend/regression types that best describe the data type. Determination of the type of regression is based on trendline reliability. A trendline is most reliable when its $\mathrm{R}$-squared value is at or near 1. Equation 2 is the trendline equation from reactor $\mathrm{ED}$ data, and Equation 3 is from reactor AC. For Equation 2 and Equation 3, the value $\mathrm{R}^{2}=0.934$ and $\mathrm{R}=0.9321$ respectively indicates a close relationship and strong correlation between the variables $x$ (time) and $y \quad(F e$ concentration). The equation can be used to predict the value of the desired variable. Meanwhile, Figure 2 shows $\mathrm{Fe}$ concentration prediction in VSSF-CW with E. dulcis dan Figure $3 \mathrm{Fe}$ concentration prediction in VSSF-CW with A. calamus based on Equation 2 and Equation 3. 
Nopi Stiyati Prihatini et.al. Study of variation of plant types of vertical subsurface constructed wetland treating groundwater contaminated with Iron $(\mathrm{Fe})$. $\begin{array}{ll}\mathrm{y}=-0,0002 \mathrm{x}^{3}+0,0171 \mathrm{x}^{2}-0,4306 \mathrm{x}+ & \mathrm{y}=-1 \mathrm{E}-05 \mathrm{x}^{4}+0,0013 \mathrm{x}^{3}-0,0431 \mathrm{x}^{2}+ \\ 4,3371 \ldots \ldots \ldots . .(\text { equation } 2) & 0,435 \mathrm{x}+2,4314 \ldots \ldots \ldots .(\text { equation } 3)\end{array}$

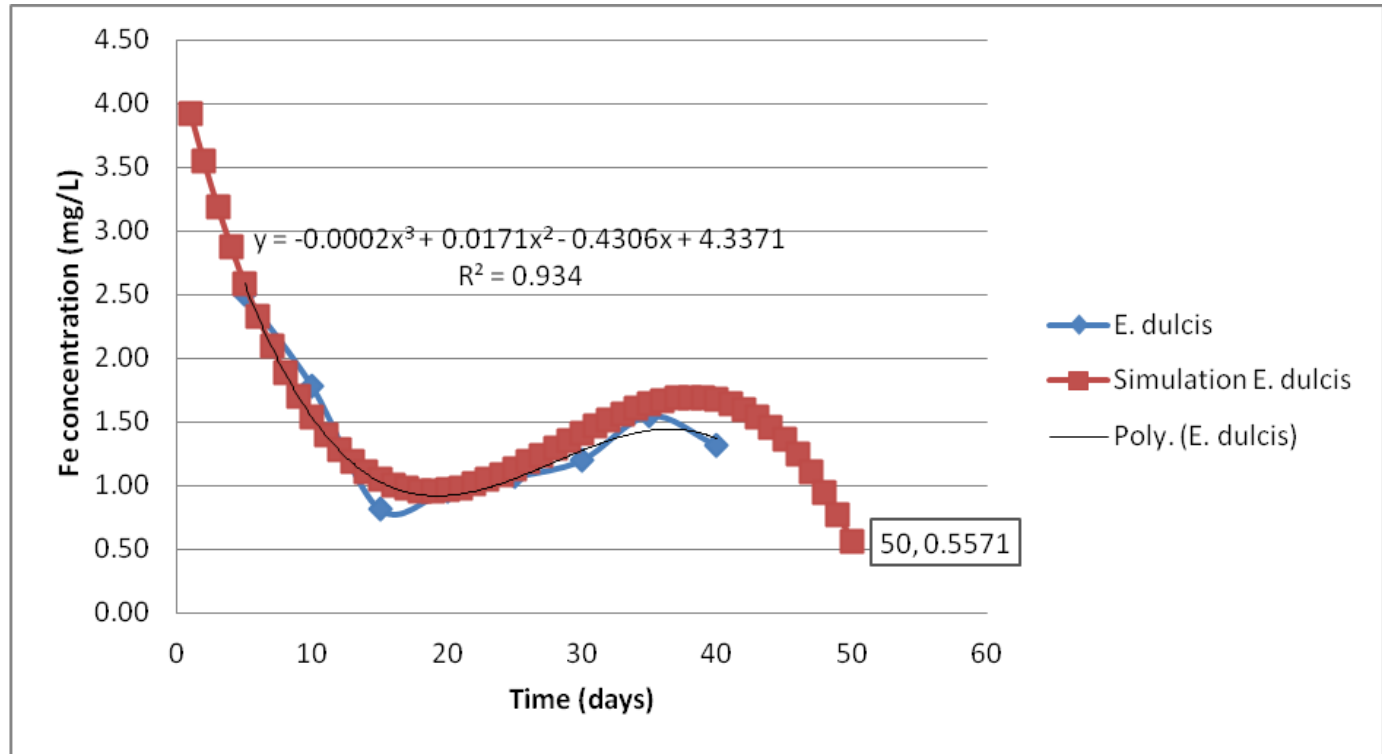

Figure 2. Fe concentration prediction in VSSF-CW with $E$. Dulcis

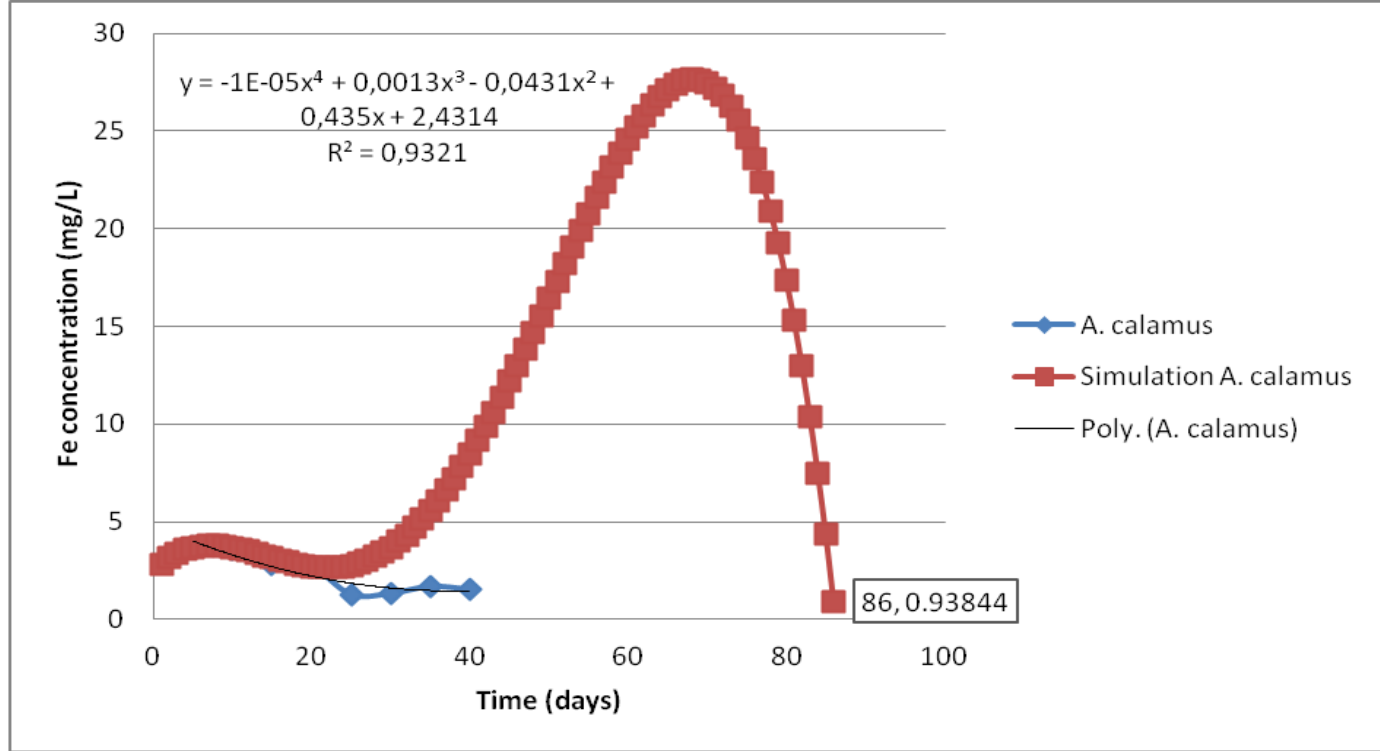

Figure 3. Fe concentration prediction in VSSF-CW with A. calamus

\section{DISCUSSION}

In table 3.1, it can be seen that the results showed that the concentration of Iron $(\mathrm{Fe})$ during the 40 days of the study for all reactors decreased after passing through the VSSF-CW system compared to before passing through the VSSF-CW system. The reactor with the $A$. calamus plant had the lowest concentration of Iron $(\mathrm{Fe})$ on the $25 \mathrm{th}$ day of $1.26 \mathrm{mg} / \mathrm{L}$; the reactor containing the E. dulcis plant had the lowest concentration of Iron $(\mathrm{Fe})$ on the 15th day of $0.82 \mathrm{mg} / \mathrm{L}$. Overall the highest concentration of Iron (Fe) occurred on day 5 with the value of each reactor, namely $A$. calamus $2.50 \mathrm{mg} / \mathrm{L}$, E. dulcis $3.72 \mathrm{mg} / \mathrm{L}$, and Control $4.22 \mathrm{mg} / \mathrm{L}$.

The concentration of Iron $(\mathrm{Fe})$ in the VSSF-CW reactor with the $A$. calamus plant (AC) continuously decreased from day 5 to day 25 , as well as the VSSF-CW reactor with E. dulcis (ED) fell from day 5 to day 15. Each reactor experienced an increase in concentration until day 35. On day 40, the $\mathrm{AC}$ reactor and $\mathrm{ED}$ reactor experienced a decrease in concentration again, but the 
value was still below $\mathrm{Fe}$ inlet concentration. While the reactor without plants $(\mathrm{C})$ has the same phenomenon as the AC reactor, it continuously decreases from day 5 to day 25 and increases concentration until day 40. The value of $\mathrm{Fe}$ removal in VSSF-CW with Acorus calamus and Eleocharis dulcis plants showed that Eleocharis dulcis plants had a more remarkable ability to remove $\mathrm{Fe}$ in VSSF-CW. This study is the same as Prihatini et al. (2017) research showed an increase in iron $(\mathrm{Fe})$ concentration with increasing time. The removal for dissolved $\mathrm{Fe}$ concentration in VSSF-CW was due to physicochemical and biological processes involving plants, media, and organisms. Physical and chemical processes consist of sedimentation, filtration, and adsorption processes.

The filtration process occurs in the media and plants that act as biofilters because of the ability of the root system in plants to form filters that can hold Fe metal in water and then absorb it into the soil. Besides that, plant roots are also a medium for attaching and growing from microorganisms that carry out biological processing. Pollutants will be reduced due to microbial metabolism, plant metabolism, adsorption by plants, and natural death by bacteria and viruses (Khiatudin, 2003).

Based on the study results, the average initial concentration of Iron $(\mathrm{Fe})$ is $5.53 \mathrm{mg} / \mathrm{L}$. The concentration of effluent Iron $(\mathrm{Fe})$ after processing in VSSF-CW on days 5-40 can be seen in Table 1. It shows that the concentration of Iron $(\mathrm{Fe})$ effluent has various outputs. There is a decrease and increase in concentration on certain days. In this study, the VSSF-CW system with each plant tended to experience a reduction in the concentration of Iron $(\mathrm{Fe})$. This decrease in iron $(\mathrm{Fe})$ concentration indicates a phytoremediation process in a constructed wetland system where the ability of soil and plants to absorb or remove Fe metal in the VSSF-CW system.

The efficiency of each reactor is shown in Figure 1. Overall, the reactor using the Eleocharis dulcis plant (ED) has a higher efficiency than the reactor using the Acorus calamus plant (AC). The highest efficiency in each reactor (ED, AC, and C) were $85.68 \%, 76.72 \%$, and $59.37 \%$, respectively. Meanwhile, the lowest efficiency of each reactor during the study was on day 5, with values of $58.28 \%$, $37.88 \%$, and $29.43 \%$, respectively. In this study, the VSSF-CW system with Acorus calamus and Eleocharis dulcis plants set aside the concentration of Iron (Fe). Still, the decrease in the concentration of Iron (Fe) that occurred in the treatment with Eleocharis dulcis plants was below the quality standard set by the Minister of Health Number 32 of 2017. It means that the VSSF-CW system with Eleocharis dulcis plants has effectively reduced the concentration of Iron $(\mathrm{Fe})$ in groundwater.

The concentration of Iron $(\mathrm{Fe})$ at the ED reactor had varying results, decreasing from day 5 to day 40 with a range of $2.50 \mathrm{mg} / \mathrm{L}$ down to $1.32 \mathrm{mg} / \mathrm{L}$. The VSSF-CW with E. dulcis plants experienced a significant decline (days 5 to 15$)$ from $2.50 \mathrm{mg} / \mathrm{L}$ to $0.82 \mathrm{mg} / \mathrm{L}$. The Eleocharis dulcis plant has a shorter adaptation time to the environment than the Acorus calamus. So that on that day, it met the quality standard according to the Minister of Health Number 32 of 2017. Then there was an increase in concentration (days 15 to 35 ) from $0.82 \mathrm{mg} / \mathrm{L}$ to 1.55 $\mathrm{mg} / \mathrm{L}$. Furthermore, the concentration of Iron $(\mathrm{Fe})$ decreased again on the 40th day from $1.55 \mathrm{mg} / \mathrm{L}$ to $1.32 \mathrm{mg} / \mathrm{L}$. In the linear regression simulation, the concentration of Iron $(\mathrm{Fe})$ will decrease until day 50 (Figure 2), and this indicates that the Eleocharis Dulcis plant is a plant with high Iron (Fe) hyperaccumulators. The highest concentration of Iron $(\mathrm{Fe})$ occurred on day 5 of $2.50 \mathrm{mg} / \mathrm{L}$. The lowest concentration of Iron $(\mathrm{Fe})$ happened on the 15 th day of $0.82 \mathrm{mg} / \mathrm{L}$.

The concentration of Iron $(\mathrm{Fe})$ in VSSF-CW with Acorus Calamus plants decreased every day for 40 days with a range of concentrations of Iron $(\mathrm{Fe})$ from 
$3.72 \mathrm{mg} / \mathrm{L}$ down to $1.53 \mathrm{mg} / \mathrm{L}$. In the $\mathrm{AC}$ reactor, the $\mathrm{Fe}$ concentration in effluent decreased (days 5 to 25 ) from $3.72 \mathrm{mg} / \mathrm{L}$ to $1.26 \mathrm{mg} / \mathrm{L}$ and again increased (days 25 to 35$)$ from $1.26 \mathrm{mg} / \mathrm{L}$ to $1.68 \mathrm{mg} / \mathrm{L}$. The increase in metal concentrations could be caused by the decrease in plant accumulation on that day. Another reason, according to Yunus and Prihatini (2018), is that constructed wetlands can act as a nonabsorbent metal source at certain times ${ }^{[12]}$. Furthermore, the concentration of $\mathrm{Fe}$ on the 40th day decreased again from $1.68 \mathrm{mg} / \mathrm{L}$ to $1.53 \mathrm{mg} / \mathrm{L}$. In a linear regression simulation, iron $(\mathrm{Fe})$ concentration will decrease on day 86 (Figure 3); heavy metals in free conditions can be toxic, so that plants will experience decreased function. The longer the water is in the constructed wetland, the longer the contact time with plants and microbes that degrade pollutants, which causes more pollutants to be degraded. However, if it is too long, it will cause saturation of the vegetation and media in accommodating the pollutant load, causing the concentration of Iron $(\mathrm{Fe})$ to rise again.

While VSSF-CW without plants (Control), the concentration of Iron $(\mathrm{Fe})$ decreased (days 5 to 25 ) from $4.22 \mathrm{mg} / \mathrm{L}$ to $2.19 \mathrm{mg} / \mathrm{L}$. Removal of iron (Fe) may occur due to the influence of gravel media, where microorganisms and algae can grow on the media and play a role in degrading and depositing particulate material (Randerson, 2006). Then the Iron ( $\mathrm{Fe})$ concentration rose again (days 25 to 40 ) from $1.68 \mathrm{mg} / \mathrm{L}$ to $2.58 \mathrm{mg} / \mathrm{L}$. The increase in concentration occurs because the system begins to experience saturation, and the media has decreased function. The saturation point is the maximum time limit that the media can tolerate in binding contaminants.

\section{CONCLUSION}

The VSSF-CW system with $E$. dulcis plant effectively removed iron $(\mathrm{Fe})$ with a higher efficiency value of $85.68 \%$ compared to the reactor with A. calamus plant that was $76.72 \%$, and reactor without plant 59,37\%. The lowest efficiency of each reactor during the study was on day 5 , with values of $58.28 \%$, $37.88 \%$, and $29.43 \%$, respectively. The concentration of iron $(\mathrm{Fe})$ in the VSSF-CW system effluent with Acorus calamus and Eleocharis dulcis plants for 40 days has a value that tends to decrease.

\section{ACKNOWLEDGMENT}

Thank you to the Lambung Mangkurat University Research and Community Service Institute for funding this research with DIPA funds from Lambung Mangkurat University 2021 Number: SP DIPA- 023.17.2.6777518/2021 November 23, 2020; Lambung Mangkurat University, Ministry of Education and Culture, by the Decree of the Chancellor of Lambung Mangkurat University Number: 697/UN8/PG/2021, March 22, 2021.

\section{Conflict of Interest: None}

\section{Source of Funding: None}

\section{REFERENCES}

1. Nurlina $\mathrm{N}$, Suhadiyah $\mathrm{S}$, Umar MR. Akumulasi Logam Berat Besi (Fe) Pada Kiapu Pistia stratiotes L. dari Air Sumur Sekitar Workshop Unhas (Heavy Metal Accumulation of Iron $(\mathrm{Fe})$ in Kiapu Pistia stratiotes L. from Well Water Around Unhas Workshop). Makassar. Prosiding Seminar Biologi. 2016; 2(1) ISBN: 978-602-722451-3 (In Bahasa)

2. Nirtha RI, Prihatini NS, Pronawati L. Penggunaan Lahan Basah Buatan Aliran Vertikal Bawah Permukaan Dengan Tanaman Typha latifolia dan Cyperus papyrus Dalam Menyisihkan Besi (Fe) Dan Mangan (Mn) Pada Air Sumur Bor. Jukung (Jurnal Teknik Lingkungan); 2021: 7(1): 95102.

https://doi.org/10.20527/jukung.v7i1.10820

3. Kumar V, Bharti PK, Talwar M, Tyagi AK., Kumar P. Studies on high iron content in water resources of Moradabad district (UP), India. Water Science. 2017; 31(1): 44-51. https://doi.org/10.1016/J.WSJ.2017.02.003

4. Kadlec, RH., Wallace, S. Treatment Wetlands. In Treatment Wetlands. CRC 
Nopi Stiyati Prihatini et.al. Study of variation of plant types of vertical subsurface constructed wetland treating groundwater contaminated with Iron $(\mathrm{Fe})$.

Press.

2008. https://doi.org/10.1201/9781420012514

5. Prihatini, NS., Soemarno. Potential of Purun tikus (Eleocharis dulcis (Burm. F.) Trin. ex Hensch) to restore the Iron (Fe) contaminated acid mine drainage by using constructed wetland. In K. Bauddh, J. Korstad, \& P. Sharma (Eds.), Phytorestoration of Abandoned Mining and Oil Drilling Sites. Elsevier. 2021. https://doi.org/10.1016/B978-0-12-8212004.00015-7

6. Prihatini, NS., Khair, RM., Nirtha, RI., Tanjung, RF. Effectiveness of Sub Surface Flow Constructed Wetland Planted With Equisetum hyemale And Iris pseudacorus to Remove Iron (Fe) And Manganese (Mn) From Ground Water. In Prosiding Seminar Nasional Lingkungan Lahan Basah. 2020: Vol. 5, Issue April.

7. Artiyani, A. Penurunan Kadar N-Total Dan P-Total Pada Limbah Cair Tahu Dengan Metode Fitoremediasi Aliran Batch Dan Kontinyu Menggunakan Tanaman Hydrilla Verticillata. 2011: Vol. 9, No. 9-14

8. Prihatini, NS, Priatmadi, BJ, Masrevaniah, A, Soemarno, S. Performance Of The Horizontal Subsurface-Flow Constructed Wetlands With Different Operational Procedures. International Journal of Advances in Engineering \& Technology. 2015; 7(6): 1620-1629

9. Basri, Syahrul, Hamzah E. Studi Eksperimen: Efektivitas Kemampuan
Tanaman Jeringau (Acorus calamus) Untuk Menurunkan Kadar Logam Berat Di Air. Higiene: Jurnal Kesehatan Lingkungan. 2015; 1(1).

10. Prihatini, NS, Soemarno, S. Iron (Fe) bioconcentration in Purun tikus (Eleocharis dulcis) planted on the constructed wetland treating the coal acid mine drainage. International Journal of Biosciences (IJB). 2017; 11(3): 69-75. https://doi.org/10.12692/ijb/11.3.69-75

11. Hedin RS, Nairn RW. Sizing and Performance of Constructed Wetlands: Case Studies. In Mining and Reclamation Conference and Exhibition, Charleston, West Virginia.1990

12. Yunus R, Prihatini NS. Fe and Mn phytoremediation of acid coal mine drainage using water hyacinth (Eichhornia crassipes) and Chinese water chestnut (Eleocharis dulcis) on the constructed wetland system. Int. J. Biosci. 2018; 12(4): 273-282.

http://dx.doi.org/10.12692/ijb/12.4.273-282.

How to cite this article: Nopi Stiyati Prihatini, Indah Nirtha, Riza Miftahul Khair et.al. Study of variation of plant types of vertical subsurface constructed wetland treating groundwater contaminated with iron (Fe). International Journal of Research and Review. 2022; 9(1): 635-641. DOI: https://doi.org/10.52403/ijrr. 20220174 